\title{
RATIONALES FOR FIRST NATIONS RUN SCHOOLS IN ONTARIO: A CONTENT ANALYSIS
}

\author{
by \\ Hiona Murray \\ Bachelor of Arts, Criminology and Criminal Justice, \\ Carleton University, Ottawa, ON, 2009
}

\author{
A Major Research Paper \\ presented to Ryerson University
}

in partial fulfilment of the requirements for the degree of

\author{
Master of Arts \\ In the Program of \\ Early Childhood Studies
}

Toronto, Ontario, Canada, 2010

CHiona Murray 2010 
I hereby declare that I am the sole author of this major research paper.

I authorize Ryerson University to lend this paper to other institutions or individuals for the sole purpose of scholarly research.

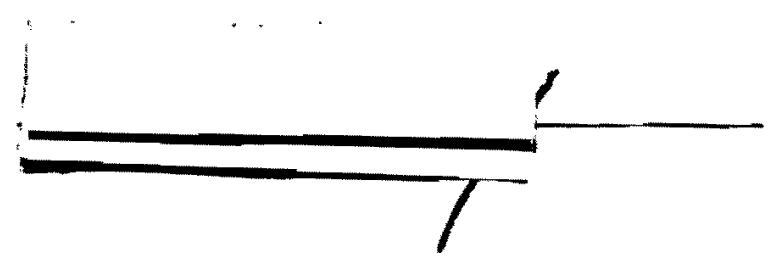

I further authorize Ryerson University to reproduce this paper by photocopying or by other means, in total part, at the request of other institutions or individuals for the purpose of scholarly research.

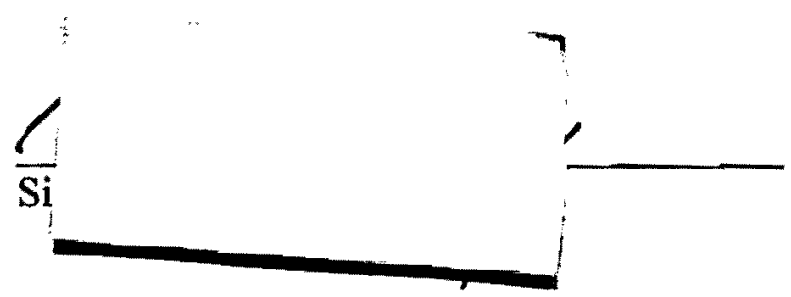




\title{
Rationales for First Nations Run Schools in Ontario: A Content Analysis
}

\author{
(C) Hiona Murray, 2010 \\ Master of Arts \\ Early Childhood Studies \\ Ryerson University
}

\begin{abstract}
The purpose of this research study was to address the question: how do First Nations leaders and scholars articulate the rationales for First Nations run schools in Ontario? Documents were collected from two First Nations websites, Assembly of First Nations and Chiefs of Ontario, and subjected to a manifest and latent content analysis. Three themes representing rationales emerged from the findings: self-governance over education, improvement of socioeconomic conditions and sustainability. An underlying rationale that linked the three themes indicated that First Nations need recognition of self-government in order to control their education system, improve its quality and enhance learner outcomes.
\end{abstract}

Keywords: First Nations; education; self-government 


\section{Acknowledgements}

The completion of this research paper would not have been possible without the support and wisdom of the following people:

I would like to thank Dr. Rachel Langford for her supervision throughout this process.

Dr. Pamela Palmater, thank you for taking the interest in my research paper, your passion and experience continue to motivate me. I appreciated your patience and constructive criticism, if it was not for you this paper would not have been completed.

I am grateful to my family who offered support including my mother Sylvia, siblings Apryl and Marko.

Thank up Lavinia for listening to my ideas and offering constructive criticism. You have been my outlet from the beginning and I am truly appreciative of that.

I would also like to thank my husband Kurt, who always take great interest in my accomplishments and encourages me to reach my goals. 


\section{Dedication}

To Kurt...you are my voice of reason 


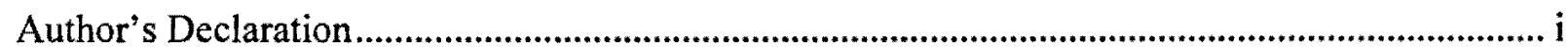

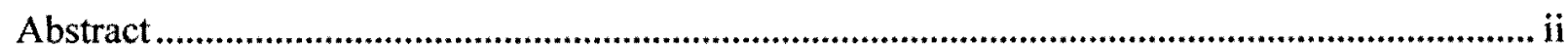

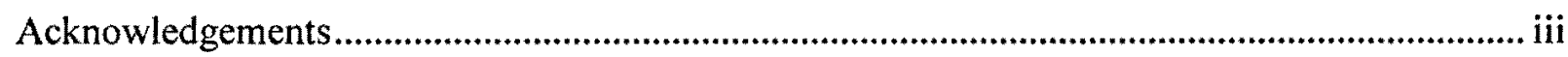

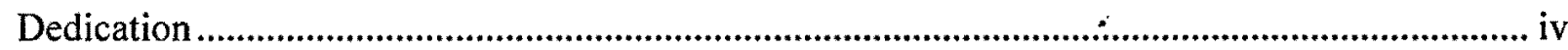

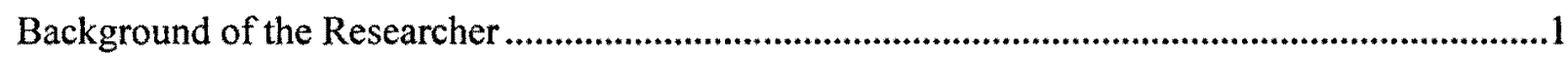

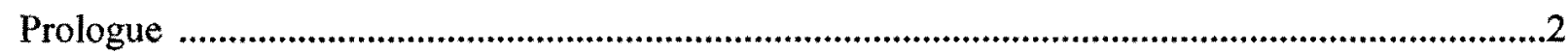

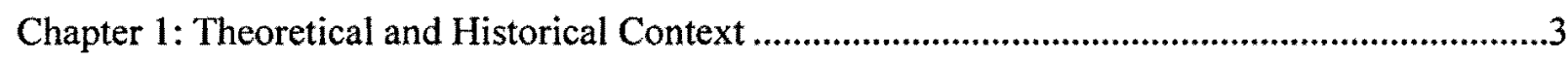

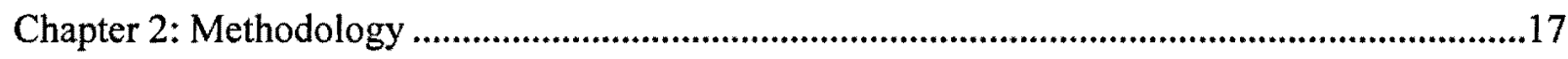

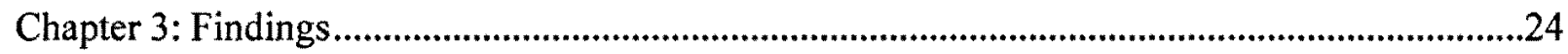

Theme 1:Self-Goverance over Education ...................................................................................

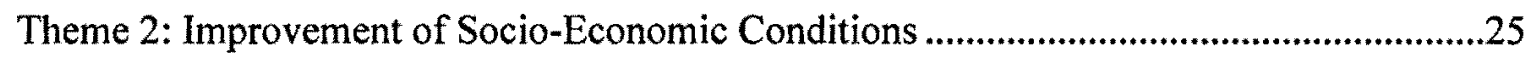

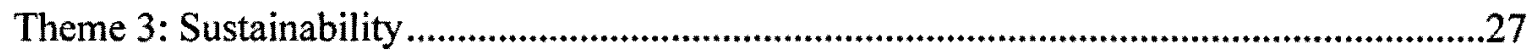

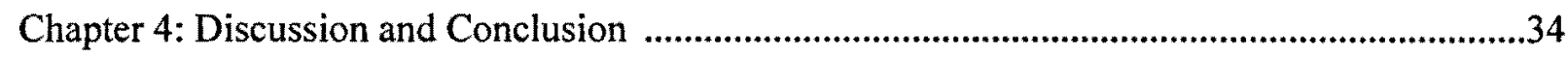

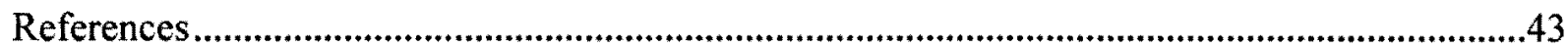

Appendix A .

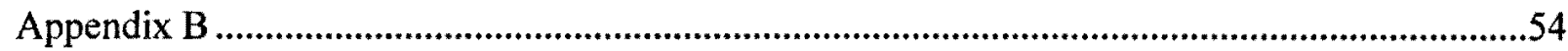




\section{BACKGROUND OF THE RESEARCHER}

As a Jamaican-Canadian, I am familiar with some of the educational struggles that face the Black community in Canada. The Black community is a minority group that has encountered discrimination and experienced oppression within an educational system. These experiences coupled with student's low graduation rates from high school and lack of cultural knowledge (Dei, 2008) have led to the implementation of Afro-Centric schools in the Toronto area. The Black community's struggles within the educational system are similar to some of the challenges that have plagued the First Nations community. I, however, recognize the limits of my knowledge of First Nations history and educational experiences; this study has been an opportunity to gain greater insights into how their experiences can be addressed. 


\section{PROLOGUE}

My inspiration for this study came from a visit to the Chippewas of Georgina Island First Nation Indian Reserve. My classmate invited me to visit the reserve on which she grew up and where she currently works. While I was on the reserve, she showed me the preschool and elementary school and I was able to observe the children's learning experiences. The children learn two dominant languages- Ojibway and English. I observed that First Nations culture, traditions and language was at the heart of the curriculum. Later, I learned that these schools among many others are managed by First Nations. I was motivated to learn more about other First Nations schools in Ontario. 


\section{CHAPTER 1: THEORETICAL AND HISTORICAL CONTEXT}

The goal of this study was to address the research question: "How do First Nations leaders and scholars articulate the rationales for First Nations run schools in Ontario?" This research study offers a preliminary analysis of these rationales. A manifest and latent content analysis of documents from two First Nations websites was used to conduct the exploration of the rationales articulated.

There are approximately 803 First Nations schools in Canada. A majority of these schools exist in the provinces of Ontario, Saskatchewan, Manitoba, Alberta, British Columbia and Quebec (Office of the Parliamentary Budget Officer, 2009). According to the Office of the Parliamentary Budget Officer (2009), there are 156 First Nations schools in Ontario. First Nations have advocated for their schools to be grounded in language, culture and traditional teachings (Waabiginoojii \& Anderson, 2004). Many First Nations believe that learning should reflects an enduring philosophy and way of living that integrates all knowledge and experience throughout the various stages of a person's life (Canadian Council on Learning, 2009). Some First Nations believe learning is a social process that fosters relationships throughout the community. These "relationships serve to transmit social values and a sense of identity, and also help to ensure cultural continuity" (Canadian Council on Learning, 2009, p. 10). Waabiginoojii and Anderson (2004) have emphasized that:

A First Nations education system will provide all students with an education that grounds them in 'who they are' as First Nations peoples. It will sustain their connections to the traditions, the land and their language. This will enable them to continue their own education with pride and this will be reflected in their contributions to the well-being of their communities (p. 3). 
These principles of First Nations run schools are consistent with the policies outlined in the 1972 policy document entitled Indian Control of Indian Education and reaffirmed in the Royal Commissions on Aboriginal Peoples 1996. To implement the principles and address a history of colonialism, First Nations have argued for more control over their schools (Indian and Northern Affairs, 1996).

Postcolonial theory was the main framework that guided this study. A post-colonial lens was used when selecting, reading, interpreting and analysing documents on First Nations run schools in Ontario. This theoretical framework is concerned with the reactions to and analysis of colonialism and "deals with the effects of colonization on cultures and societies" (Ashcroft, Griffith \& Tiffin, 2001, p.186). In other words, post-colonial theory examines the issues of the past in order to address the problems of the present.

Spivak, Said and Bhabha are some of the theorists whose works have contributed to the development of this theory. Spivak was the first to use the term post colonial "in the collection of interviews and recollections published in 1990 called The Post-Colonial Critic" (Ashcroft, Griffith \& Tiffin, 2001, p.186). The term, post-colonial, originally referred to the interactions between different cultures within colonial societies, but after the 1960 s, the focus was on "the political, linguistic and cultural experiences of societies that were former European colonies" (Ashcroft, Griffith \& Tiffin, 2001, p.186). Furthermore, theorists Said, Spivak and Bhabha influenced many critics to focus "on the material effects of the historical condition of colonialism, as well as on its discursive power, to insist on the hyphen to distinguish postcolonial studies as a field from one aspect of the many approaches and interests that the term 'post-colonial' sought to imagine and discuss" (Ashcroft, Griffith \& Tiffin, 2001, p.187). Postcolonialism is now used to refer to: 
The study and analysis of European territorial conquests, the various institution of European colonialisms, the discursive operations of empire, the subtleties of subject construction in colonial discourse and the resistance of those subjects, and, most importantly perhaps, the differing responses to such incursions and their contemporary colonial legacies in both pre-and post-independence nations and communities (Ashcroft, Griffith \& Tiffin, 2001, p.187).

Post-colonialism is not limited to the study of how societies have recovered from a colonial experience but can extend to taking on a transformational position, seeking social change (Viruru, 2005). In the words of Young (2001, p. 58), such change can "emerge on different sites in any region: the academic, the cultural, the ecological, the educational...and the social sphere." In this study, a postcolonial perspective provided insight into the historical and current education conditions for First Nations.

In 2006, the Aboriginal population reached $1,172,785$, representing $4 \%$ of Canada's total population (Indian and Northern Affairs Canada, 2006). Aboriginal peoples "is a collective name for the original peoples of North America and their descendants" (Indian and Northern Affairs Canada, 2010, p.1). There are three groups of Aboriginal people recognized in section 35(2) of the Constitution- Métis, Inuit and Indian (Canadian Constitution, 1982). The total Aboriginal population includes 53\% Registered Indians, 30\% Métis, $4 \%$ Inuit and 11\% nonstatus Indians. Métis refers to "people of mixed First Nation and European ancestry who identify themselves as Métis, as distinct from First Nations people, Inuit or non-Aboriginal people" (Indian and Northern Affairs Canada, 2010, p. 2). The unique culture of the Métis is a combination of their diverse ancestral originals, including French, Ojibway, Scottish and Cree (Indian and Northern Affairs Canada, 2010). The term Inuit refers to "an Aboriginal people in Northern Canada, who live in Nunavut, Northwest Territories, Northern Quebec and Northern 
Labrador (Indian and Northern Affairs Canada, 2010, p. 2). Although, the term Indian, is still in the Constitution, many find the term to be offensive.

In the 1970 s, the term, First Nation, came into usage to replace the term 'Indian'. The term 'First Nations peoples' is commonly used to refer to "the Indian peoples in Canada, both Status and non-Status. Some people have also adopted the term "First Nation" to replace the word "band" in the name of their community" (Indian and Northern Affairs Canada, 2010, p. 1).

In this study, I will be using the term, First Nations, to describe and include various First Nations communities in Ontario. Of the 134 First Nations communities in Ontario, there are 13 nations of Indigenous people which have different language, cultures and traditions (Powless, 2004). These nations "are the Algonquin, Mississauga, Ojibway, Mohawk, Seneca, Tuscarora, Cree, Pottowatomi, Cayuga, Onondaga, Odawa and Delware" (Powless, 2004, p.2). For the purposes of this study, I will use the term, First Nations, to include all First Nations that reside within Ontario.

In keeping with my post-colonial theoretical framework, I now turn to examine the issues of the past. For the first hundred years of European contact, First Nations and the colonizers peacefully co-existed. That is, early settlers, whalers, and traders relied on First Nations knowledge of the environment for their survival and livelihood (Warry, 2007). Once the colonizers were settled, however, they believed that it was their duty to convert First Nations peoples to European culture. Their ultimate goal was to gain control over land and resources. Various policies were designed to assimilate First Nations so they could become "civilized" by adopting European customs (Warry, 2007).

One of the earlier forms of colonialism was the physical, social, cultural and political displacement of the Indigenous population. The physical displacement occurred when they were 
not permitted to enter their traditional territories and land. In some cases, Aboriginal peoples were forcibly relocated to reserves where they were encouraged to farm and learn European skills and values. The social and cultural displacement also occurred with the establishment of residential schools. These schools undermined the ability of elders and community members to pass on values and customary traditions to Aboriginal children and who were instead forced to learn European values and forbidden to participate in traditional activities and ceremonies (Indian and Northern Affairs Canada, 1996). Residential schools were employed as a chief strategy to assimilate First Nations into the European culture.

Residential schools were of two types: boarding and industrial. Students were supposed to attend boarding schools until they reached the age of fourteen. These schools were typically located near reserves in order to draw large numbers of First Nations children from the surrounding region. Industrial schools, on the other hand, usually were located close to white population centres and far from First Nations villages (Furniss, 1992). The industrial schools were considered more sophisticated than boarding schools since, in addition to acquiring basic reading and writing skills, children could be trained in skills such as trades, agricultural, and domestic labour. Both boarding and industrial schools were founded on the belief that First Nations children needed to be segregated from their families and their cultural environment. In the case of the industrial schools, the level of segregation was more severe (Furniss, 1992). These government policies and practices were aimed at encouraging or forcing First Nations to assimilate into the dominant culture (Warry, 2007). Legislations, like the Indian Act 1876, gave more responsibility to the government for the education of First Nations learners.

Gradually, with the aid of the Indian Act, Aboriginal peoples "control and management of their own lands and resources, and their traditional customs and forms of organization were 
interfered with in the interest of remaking Aboriginal people in the image of the newcomers" (Indian and Northern Affairs Canada, 1996, p. 3). In 1884, the Indian Act specified that the attendance of children, in residential schools, between the ages of six and fifteen was mandatory (Stout \& Kipling, 2003). This revision also coincided with the approval of Davin's (1879) report and recommendations on Indian industrial schools which emphasized aggressive civilization for 'Indians' through education. In addition, the Governor in Council, and not Chiefs and Councils, possessed the full legal authority to make regulations pertaining to the designation or establishment of industrial or boarding schools, mandatory attendance until the age of eighteen, the arrest and detention of truant children under the age of sixteen by an Indian Agent, penalties for parents and guardians who wilfully withheld their children from school and the application of children's annuities towards their care at school, or to the costs of maintaining the school. In 1894, these recommendations were included under Section 11 of the Indian Act (Treaties and Historical Research Centre, 1978).

In 1920, the Indian Act was amended making it mandatory for all First Nations children until the age of eighteen to attend school (Walker, 2009). With the 1920 amendments, day schools were approved as educational institutions for First Nations children alongside with the residential boarding and industrial schools. Indians Affairs also undertook to pay for children's transportation to and from residential schools, including their travel costs for yearly vacations (Jaine, 1993). Indian Affairs stipulated, however, that children had to be placed in the nearest available school of their religious denomination. The old isolationist policy of removing children as far away as possible from home was no longer the case as the financial costs became too much for the government. In addition, to address these costs the age bracket for mandatory attendance at school dropped to between the ages of seven and fifteen years old (Jaine, 1993). 
First Nations children were not permitted to attend any other educational institution except one which was legally recognized as an Indian school. A First Nations child could attend a public or private school, but only if their parents wished to become enfranchised (Williamson, 1999). Jaine (1993) aptly stated: "resisting the 'Christianizing and civilizing' influences of the church and state was an onerous task. The government had the force of law behind it; the church had God" (p.43).

Residential schools existed in Canada for close to a century and a majority of these schools were operated by the Roman Catholic Church; however, others were run by the Anglican and United Churches. In some cases, the federal government assigned the responsibility for the education of First Nations children to the Roman Catholic, Anglican or United Church. The implementation of the religious component was thought to speed up the process of assimilation (Furniss, 1992). The religious foundation of the residential school, however, did not prevent the frontline personnel from subjecting First Nations children to ritualized abuse (The Aboriginal Healing Foundation, 2005). Ritualized abuse refers to abuse which is "repeated, systematic, sadistic and humiliating trauma to the physical, sexual, spiritual and/or emotional health of a person that may utilize techniques, including but not limited to, conditioning, mind control and torture" (The Aboriginal Healing Foundation, 2005 p. 35). For example, First Nations children were isolated and deprived of their families and social supports and could not practice their culture or report the abuse. The conditions of residential schools for First Nations children were worse than the living conditions on the reserves. Constant under-funding produced unhealthy living conditions, malnutrition, low quality education, and inadequate training and supervision of staff (Furniss, 1992). 
By the mid 1970s, many of the residential schools had closed; however the last school in Canada did not close until 1996 (The Aboriginal Healing Foundation, 2005). While a few students have retained positive memories of the years spent in a residential school, the majority have negative memories of physical beatings, rapes, food deprivation, long hours of isolation and harsh labour (Williamson, 1999).

The abuse and neglect that some First Nations suffered while at a residential school have affected their adult lives, as well as the lives of their descendants. Intergenerational effects refers to "the effects of ....abuse(s) that were passed on to the children, grandchildren and greatgrandchildren of First Nations people who attended the residential school system" (The Legacy of Hope Foundation, 2001). Such effects include alcohol and drug abuse, sexual and physical abuse, high school dropout rates and cultural identity issues. According to the most recent statistics, approximately 70 percent of First Nations learners will not complete high school. The annual graduate rates for First Nations students on reserves range from 28.9 percent to 32.1 percent. At this current rate, the Assembly of First Nations estimates that it will take 28 years before First Nations students can catch up to the graduation rates of the non-Aboriginal population (Assembly of First Nations, 2007). These are the "material effects of the historical condition of colonialism" (Ashcroft, Griffith \& Tiffin, 2001, p.186) as described by post-colonial theorists. These effects have caused generations of First Nations to be unaware of their history, tradition and culture. The federal government has attempted to acknowledge their role in the implementation of the residential school system and its intergenerational effects.

On September 19,2007, the Indian Residential Schools Settlement Agreement came into effect. This agreement is the result of the class action and other lawsuits brought against the Canadian Government and the individuals associated with the Church who were involved in 
running residential schools (Feldthusen, 2007; Service Canada, 2008). The Common Experience Payment (CEP) is one component of the settlement agreement which recognizes the experience of residing at a residential school and its effects (Service Canada, 2008). Compensable abuse includes physical and sexual abuse and actions, perpetrated by adult employees and other adults permitted to be on school premises, causing serious psychological consequences (Tillotson, 2002). It extends to abuses committed by individuals on and off schools premises and committed when school was in and out of session. Abuse committed by students is also covered, provided that the claimant can establish actual and constructive knowledge that school officials were aware of the occurring abuse and took no reasonable steps to prevent it (Tillotson, 2002). The Common Experience Payment is one example of how the government has attempted to resolve the experiences of former residential school students. The other way has been through a public apology.

Many survivors, Indigenous organizations and advocates have demanded an apology from the Canadian government for the role Canada played in the development and administration of residential schools, separating families and impeding with the transmission of First Nations language and culture. On June 11 2008, Canadian Prime Minister Steven Harper delivered an apology for the horrible treatment of Aboriginal peoples at residential schools. Harper called residential schools a "sad chapter" in Canada's history. He further went on say that the government recognizes that the assimilation of Aboriginal children was wrong and "has caused great harm and has no place in [Canada]" (CBC News, 2008). Further, Harper stated that the "policy was profoundly damaging to the language and heritage of [First Nations and the residential] schools' legacy includes social problems that persist in communities today" (Prime Minister of Canada, 2008, p.1). Aboriginal leader Phil Fontaine responded to the government 
apology stating that "the memories of residential schools sometimes cut like merciless knives at our souls. This day will help us to put that pain behind us" (CBC News, 2008). This apology is just one piece of a much larger puzzle of addressing the legacy of residential schools.

Another piece and problem is that the Indian Act remains the statute that legally that regulates the education of First Nations on reserves today (Mendelson, 2008). Section 114 (1) reads:

The Governor in Council may authorize the Minister, in accordance with this Act, to enter into agreements on behalf of Her Majesty for the education in accordance with this Act of Indian children, with
(a) the government of a province;
(b) the Commissioner of Yukon;
(c) the Commissioner of the Northwest Territories;
(c.l) the Commissioner of Nunavut;
(d) a public or separate school board; and
(e) a religious or charitable organization.

The Act is inconsistent with current practices in federal and First Nations responsibilities for the provision of First Nations education on reserves.

In 1974, the federal government started to fund First Nations schools on reserves and there was a decline in the number of federally operated schools (Mendelson, 2008). Funding band councils and First Nations education remains under the responsibility of Department of Indian and Northern Affairs Canada (will be interchangeably referred to as the Department and Indian and Northern Affairs Canada). The monetary obligation of the Department means that they are financially responsible for First Nations learners attending an elementary or secondary school on reserve (Indian and Northern Affairs Canada, 2008). Federal funding pays for instructional services, transportation, counseling, financial assistance, accommodation and schools administration and evaluation (Indian and Northern Affairs Canada, 2008). 
Indian and Northern Affairs Canada spends approximately 1.2 billion dollars for the operation and maintenance of 515 First Nations schools across Canada in order to support 120,000 First Nations students (Indian and Northern Affairs Canada, 2008). An estimated 60\% of students attend school on a reserve managed by band councils or First Nations organizations; while the remaining $40 \%$ attend off-reserve schools under provincial authority (Indian and Northern Affairs Canada, 2008). Indian and Northern Affairs Canada are responsible for meeting the legal obligations set out by the Canadian government and commitments to First Nations, and for fulfilling the constitutional responsibilities the federal government made to the North.

However, investigations have indicated that the Department has failed to carry out its responsibilities (Mendelson, 2008). Due to some concerns about Indian and Northern Affairs Canada, the Auditor General undertook an audit of the Department and reported her findings in a 2000 report. She observed that "many departmental regions interpret their major role as [one] of providing a funding service. Only one of seven regional offices maintains an education program; however even there, the major priority is to negotiate and provide education funding" (Office of the Auditor General, 2000, p 4-10). In 2004, the Auditor completed a follow up to her 2000 report. She concluded that "Indian and Northern Affairs Canada could not demonstrate whether it was meeting its stated objective in assisting First Nations living on reserves in achieving their education needs" (Office of the Auditor General, 2004, p.6). She also found that "the Department needed to articulate its role in education, take action to resolve outstanding issues, develop and use appropriate performance measures, and improve its operational performance" (Office of the Auditor General, 2004, p. 6).

The 2004 report further stated a concern with "the Department's lack of progress in defining its roles and responsibilities. In our view, until the Department clarifies these and its 
capacity to fulfill them, and reaches a consensus with other parties on their own roles and responsibilities, it will remain difficult to make progress in First Nations education and close the gap" (Office of the Auditor General, 2004, p.12). In response to the 2000 report, the Department established a dedicated education branch to become more involved in the education on reserves. However, in 2004 the Auditor General was still concerned about the Department's education branch as in her perspective it does not "purport to be a source of educational support and consequently does not include many personnel with educational credentials" (Mendelson, 2008, p. 44).

The lack of defined roles and responsibilities of the Indian and Northern Affairs Canada has many implications for First Nations education system. First, it is not clear if there is a regulatory system that is comparable to provincial standards. Second, there are no policies which states any commitments by the Department to fund First Nations run schools at the same level as provincial schools (Mendelson, 2008). An assessment of First Nations students' attending on reserves schools revealed that they are two grades behind public schools.

The Auditor General concluded in her 2004 report: "At present, the Department does not know whether the funding provided to First Nations is sufficient to meet the education standards it has set and whether the results achieved, overall and by the different delivery mechanisms, are in line with the resources provided" (p. 15). The Auditor General recommended that the Department should clearly establish their roles and responsibility concerning the funding, operation and maintenance of First Nations schools. It was also suggested that they should do annual comparability surveys to ensure that the federal funding provided to on-reserve schools are comparable to provincial schools. 
From the perspectives of First Nations, education "provides the setting in which First Nations children can develop the fundamental attitudes and values which have an honoured place in First Nations' traditions and cultures" (Assembly of First Nations, 1988, p.71). Battisite and Barman (1995) defined the goal of First Nation education as "salvaging... [First Nation] languages, cultures, and societies and transmitting those cultures, with their unique understanding of North American ecology and their distinctive world views" (p. viii-ix). The Royal Commission on Aboriginal Peoples, 1996 have outlined two educational goals for First Nations learners. First, the Commission viewed the education system as a way to provide First Nations students with the skills they need to be participating members in society. Second, education is the means for First Nations "children to develop as citizens of Aboriginal Nationswith the knowledge of their languages and traditions necessary for cultural continuity" (Indian and Northern Affairs Canada, 1996, Volume 5.0).

The Canadian Council of Learning aims to improve the learning experience for all Canadians by providing information about the learning environments and promoting and supporting quality research on learning. They have also attempted to understand the role learning plays in building healthy and prosperous First Nations communities (Canadian Council of Learning, 2009). The Canadian Council of Learning (2009) has identified "three foundational themes based on place, spirit and ...language which form the basis of Indigenous knowledge and knowing ..." (p. 4). Battiste (2002) has maintained that First Nation schools allow for multiple intelligences of First Nations students to shine as these schools provide multiple ways of learning. This scholar stated that "First Nation pedagogy values a person's ability to learn independently by observing, listening and participating with minimum... intervention or instruction. This pattern of direct learning by seeing and doing, without asking questions, makes 
[First Nations] children diverse learners" (Battiste, 2002, p. 15). Although one of the purposes of First Nations schools is to integrate First Nations culture into the curriculum, students are still required to meet and follow the provincial academic standards in order to fulfill graduation requirements (McDonald, 2004).

Faries' (2004) research on First Nations- specific curriculum surveyed 44 schools on Ontario reserves and found that 29 schools promoted First Nations knowledge through world view, values, teaching and legends. Twenty-six schools reported that Aboriginal history is a priority which includes the historical relationship between First Nations and Canadian government, treaties and the Indian Act. First Nations skills including craft-making, traditional cooking and art were being taught in 26 schools. Eighteen schools offered First Nations spirituality which includes ceremonial and sacred teachings and smudging. As noted at the beginning of this chapter, in the section on postcolonial theory, this curricula has been designed to help First Nations recover from a colonial experience and to take on a transformational position in order to lead to social change (Viruru, 2005). 


\section{CHAPTER 2: METHODOLOGY}

A content analysis methodology was used for this study. Content analysis is an unobtrusive type of research that studies "recorded human communications" (Babbie and Benaquisto, 2002, p. 285). Content analysis is defined as a "research technique for making replicable and valid inferences from texts (or any other meaningful matter) to the contexts of their use" (Krippendorff, 2004, p. 18). Some forms that are suitable for study are books, speeches, letters, web pages, laws and constitutions (Babbie and Benaquisto, 2002). For the purposes of this research study, the content analysed were documents from two websites which offered rationales for First Nations run schools in Ontario. The current study was interested in how the rationales provided by leaders and scholars justified the implementation of First Nations run schools.

Latent content analysis is the underlying meaning of text, the depth of the communication (Babbie \& Benaquisto, 2002). Reading texts, phrases, or paragraphs is a qualitative process as the reader interprets the meaning of the written word. This type of content analysis tends to produce different perspectives which ultimately affect the reliability of the data (Babbie \& Benaquisto, 2002). This is one of the disadvantages of using only a latent content analysis approach, but when combined with manifest content analysis the reliability of the data is accounted for. Manifest content analysis, on the other hand, is easily observable, such as a written word or phrase in a text (Babbie \& Benaquisto, 2002). In order to enhance reliability, manifest content analysis omits any interpretation because it requires numerical accounts of the data (Krippendorff, 2004). In other words, manifest content analysis is the consistent component of content analysis because it is a quantitative tool. My decision to use both methods of content analysis in this study allowed me to gain a fuller understanding of what has been written about 
First Nations run schools in Ontario. Additionally, there is limited literature on the topic which also warranted this type of methodology.

I used content analysis to examine the documents produced by First Nations leaders and scholars to explore my main research question, while taking into account possible sub questions:

- Is there more than one theme?

- Are there multiple rationales for First Nations run schools?

- How do the reasons differ among the sample group?

- Are differences related to the year of publication?

The data analysis was comprised of primary texts that were written or produced by First Nations leaders or scholars, specifically, non-government reports published within the last ten years on two First Nation websites. The Assembly of First Nations and Chiefs of Ontario websites were selected because they provided resources about First Nations education in Ontario by First Nations. Although the documents obtained by the Assembly of First Nations do not specifically mention Ontario in its content, they do address First Nations education issues that Canada currently faces which directly affects Ontario. The resources collected were informative and current, which allowed for a thorough analysis of the data. It is, however, important to note that this study's exploration into the rationales for First Nations run schools is only a preliminary analysis. Two websites were chosen because of the specific criteria of the selection process. A website was selected if it was designed for or by First Nations; it had current information about First Nations run schools in Ontario and if the documents on the website were written by First Nations leaders or scholars. The Assembly of First Nations and Chiefs of Ontario websites met these criteria. 
The Assembly of First Nations is an organization comprised of Chiefs which nationally represents First Nations in Canada. They are representatives for over 630 First Nations communities in Canada (The Assembly of First Nations, 2010). The Assembly of First Nations is affiliated with the following Ontario's First Nations organizations: Chiefs of Ontario, Anishinabek Nation, Union of Ontario Indians, Association of Iroquois \& Allied Indians and Grand Council Treaty No. 3 (The Assembly of First Nations, 2010). The overall structure of the Assembly of First Nations "is based on the Charter of the Assembly of First Nations, which was adopted in July $1985 \ldots$... [This organization comprises of various positions; each role greatly contributes to its success.]... The principal organs of the Assembly of First Nations are: the First Nations-in-Assembly; the Confederacy of Nations; the Executive Committee; the Secretariat (AFN/NIB); and the Council of Elders" (Assembly of First Nations, 2010, p.1).

Documents from the Chiefs of Ontario website were also selected for analysis. The Chiefs of Ontario is a committee formed of First Nations Chiefs residing in Ontario to provide representation of First Nations in Ontario. This committee coordinates over 130 First Nations communities within Ontario. Furthermore, the purpose of this organization is "to enable the political leadership to discuss regional, provincial and national priorities affecting First Nations in Ontario and to provide a unified voice on these issues" (Chiefs of Ontario, 2010a, p. 2). This means that the organization aims "to facilitate the discussion, planning, implementation and evaluation of all local, regional and national matters affecting the First Nations people of Ontario" (Chiefs of Ontario, 2010b, p.1). This includes the education of First Nations children.

Two documents were selected from the Assembly of First Nations website: First Nations education plan (2005) and First Nations control of First Nations education: It's our vision, it's our time (2010). The first document was chosen because it discusses the educational conditions 
for First Nations in Ontario. Specifically, it talks about the right of First Nations to have control over the education of their learners. This document also addresses the elements of First Nations education and the benefits of First Nations teaching methods for students and the community.

The second document addresses the Indian Control of Indian Education 1972 policy paper. This document examines previous legislations asserting that the right to education is an inherent Aboriginal and treaty right. This document also offers recommendations that may facilitate future changes to the First Nations education system including programs, services and policies. The elements of lifelong learning vital to First Nations culture are also explained.

All of the documents from the Chiefs of Ontario website are parts of the Chiefs of Ontario's Manifesto. Specifically, "twenty-four writers produced distinct papers according to a research framework designed to give Chiefs and their negotiators easy access to an orderly and complete picture of every aspect of education" (Chiefs of Ontario, 2004, p. 4). Only the articles that specifically discuss First Nations run schools in Ontario were selected for analysis. The following is a summary of the selected documents.

The Chiefs of Ontario's document entitled, Elements of quality First Nations education systems (2004), focuses on the evolution of the education system for First Nations in Ontario. The document begins with a discussion about the policy paper Indian control of Indian education published in 1972 about the need for a quality education for First Nations. Specifically, the document reports on how quality education is defined by its ability to be representative of the cultures, traditions and languages of First Nations. The document also addresses the consequence of the implementation of residential schools with respect to the First Nations and their cultures, customs and language. New approaches and changes to the education system for First Nations in Ontario are also discussed. 
The research paper, Standards for quality education: Towards a framework for affective and effective schools in a First Nations environment (2004), was written by Dr. Rose-Alma J. McDonald and prepared for the Chiefs of Ontario. McDonald is a First Nations woman who held the position of Director of Education with the Assembly of First Nations since 1987 (McDonald, 2008). This research paper discusses the standards for quality education in a First Nations environment.

Richard C. Powless is the author of the article, The new agenda: Building upon the history of First Nations education in Ontario (2004). As a band member of six Nations, Powless uses his prior employment experience which consists of being senior advisor to two national chiefs and two regional chiefs to advance the interests and rights of Aboriginal peoples at the international, national, regional and local levels (Kennedy, 2006). This document discusses the reasons and justifications for First Nation education. It begins by discussing education as a way to pass on traditions, culture and norms of a community to the next generation. The document also discusses the history of First Nations education, court decisions and the concept of selfgovernment.

Cythnia Wesley-Esquimaux wrote the article, Report on First Nations' governance over education: Reclaiming the circle of learning (2004). She is a member of the Chippewa of Georgina Island First Nation in Lake Simcoe and is committed to educating the general public about how Native peoples have contributed to the history and culture of Canada (Liberal Part of Canada, 2010). This document discusses the most important issues facing First Nations regarding education and governance as well as the outcome of a chain of consultation meetings arranged by Chiefs of Ontario with particular emphasis on educational interests and needs (refer to Appendix A for a summary of analyzed documents). 
I began my research process by identifying potential rationales in the documents described above, and then I categorized the rationales by selecting key words or phrases and recorded these codes on the coding sheet (see Appendix B). There were portions of each document that were excluded to avoid the analysis of unnecessary information including the title page, table of contents, executive summary, bibliography/reference page(s) and appendixes. I manually counted the number of times each rationale was explicitly mentioned in each document. After the manual coding was completed, the information was imputed into software called NVIVO 8. NVIVO 8 is "software that helps [researchers] to work with unstructured information like documents, surveys, audio, video and pictures - so that you can ultimately make better decisions" (QSR International, 2007, p. 1). Essentially, I scanned each document onto NVIVO 8, and then I coded each rationale using the software. Each item was coded because the particular word was used or because the sentence implicitly referred to the code/rationale. For example, the rationale, self-government, was coded in the following sentence "The vision of a First Nations Education Action Plan is the development and implementation of sustainable education systems under the full control and jurisdiction of First Nations based on the recognition of inherent Aboriginal and treaty rights, and under international law" (Assembly of First Nations, 2005, p. 1). Following this process, I identified the themes that emerged from the associated categories. Once the creation of categories and themes was completed the information was organized and presented in the next chapter on findings.

Replication is significant to validity in social science research (Babbie, 2004; Krippendorf, 2004). In order to ensure the accuracy of this study, I have mapped out the goal and nature of the study along with information on the sample texts, the reasons why the documents were selected and potential biases in order for researchers to replicate this research. Accordingly, 
a content analysis is valid "if the inferences drawn from the available texts withstand the test of independently available evidence, of new observations, of competing theories or interpretations, or of being able to inform successful actions" (Krippendorf, 2004, p. 313). To increase the accuracy of the coding process, and trustworthiness of the results, I have utilized the Coding Working Sheets (see Appendix B) and used the NVIVO 8 software in order to carefully compare the findings of the content analysis.

I have also stated the potential biases of the study which may account for any variations in the findings. In a qualitative study where I am the primary interpreter, external influences will have an effect on my ability to analyze the data. I am aware that my personal biases are produced based on life experience. I have clarified any biases that I have brought to this study (see background of the researcher) and kept these in mind while analyzing the data.

Furthermore, two random documents, one selected from the Assembly of First Nations and the other from the Chiefs of Ontario were chosen by the researcher's supervisor to determine whether the same codes could be found when coded independently. This was to determine whether two researchers who have different experiences and backgrounds could achieve similar results. Inter-reliability refers to "the degree to which different raters/observers give consistent estimates of the same phenomenon" (Trochim, 2006, p.1). In this study, the two researchers independently read the documents and arrived at similar codes. This shows that the data presented is reliable and the opportunity to replicate and duplicate exists. 


\section{CHAPTER 3: FINDINGS}

Based on a manifest content analysis of each document collected, three major themes emerged: self-governance over education, improvement of socio-economic conditions and sustainability. Each theme was related to sub themes/categories which will be reviewed in this chapter. These themes together make up a First Nations education rationale discourse. The following is a summary of the emergent themes and sample categories that were coded. Each will be introduced with their definition followed by a synopsis of the findings.

\section{Theme 1: Self-Governance over Education}

Self-governance over education is "formal recognition, through signed Agreements, by the federal and provincial governments of a First Nation's right to make decisions about the education of its children" (First Nations Education Steering Committee, 2008, p.1). Under this theme, the categories of inherent rights, control and self-government were coded. Within this theme, I am going to focus on the category of self-government. Below is a detailed report of the frequency of this category/rationale.

\section{Self-Government}

Self-government within the First Nations context was defined according to Dacks' definition, as the authority for First Nations "to design a diversity of forms for their governing institutions so that these [educational] institutions will reflect their diverse traditions, needs and preferences" $(2004$, p. 671). The code, self-government, was consistently found in 6 of the 6 documents. It was referenced a total of 59 times. It was referenced $15.09 \%$ in the document First Nations Action Plan; $2.46 \%$ in Elements of quality First Nations education systems; $1.22 \%$ in Standards for quality education: Towards a framework for affective and effective schools in a 
First Nations environment; $2.85 \%$ in The new agenda: Building upon the history of First Nations education in Ontario; $5.79 \%$ in the document Report on First Nations' governance over education: Reclaiming the circle of learning and $2.92 \%$ in First Nations control of First Nations education: It's our vision, it's our time. Sentences or phrases that expressly stated or suggested self-government as a rationale for First Nations run school were coded. The following are examples:

First Nations hold the strong view that they have the right of self-determination and to freely determine how they will govern themselves (Chiefs of Ontario, 2004, p.1).

The education of children is a fundamental tool in developing and strengthening self-government in First Nation communities (McDonald, 2004, p. 8).

They felt that the current structure does not value their unique views or philosophy; and the need to provide high quality education for their youth that supports their needs and values their life experience, history, culture, traditions and languages; and the fact that the Royal Commission on Aboriginal Peoples (RCAP) recognized that education is the core element of jurisdiction in First Nations self-government and that the current system is flawed and does not meet the needs of our students (Powless, 2004, p.14).

\section{Theme 2: Improvement of Socio-Economic Conditions}

This theme focuses on the possible educational outcomes for First Nations learners if they are educated in schools run by First Nations. First Nations believe that education is the key to solving some of their present social and economic conditions. Within this theme, the text was coded as educational and social and economic outcomes. It is argued that successful educational outcomes will lead to improvements to the social economic conditions for First Nations. Below is a report of the frequency of the category/rationale of social and economic outcomes. 
The rationale, social economic outcomes, is defined as the ability for education to impact the current or future conditions of First Nations learners and community. A phrase and/or sentence that explicitly or implicitly expressed social and economic outcomes' as a rationale was coded. The following texts illustrate how the category of social and economic outcomes was coded:

The federal government must therefore support First Nations education, skills development and training as a tool for nation building, and must address immediate challenges facing First Nations in other areas that directly affect First Nations educational outcomes and quality of life, such as housing, clean drinking water, infrastructure, environment, and child welfare (Assembly of First Nations, 2005, p.3).

Although factors other than education can affect the demand for social assistance, it has been demonstrated that education, or lack of it, is directly related to jobs, income levels and the potential for well being (McDonald, 2004, p. 9).

Education for First Nations provides for economic opportunities and benefits for non-Aboriginal institutions and communities, e.g. tuition, child care, rentals, purchase of services, food, etc (Chiefs of Ontario, 2004, p.8)

The examples above emphasis that First Nations run schools have the potential to transform social and economic realities.

The rationale, social and economic outcomes, was found in all 6 documents. It was referenced a total of 37 times. It was referenced $6.18 \%$ in the document First Nations Action Plan; $1.68 \%$ in Elements of quality First Nations education systems; $2.85 \%$ in Standards for quality education: Towards a framework for affective and effective schools in a First Nations environment; $0.65 \%$ in The new agenda: Building upon the history of First Nations education in Ontario; $2.35 \%$ in the document Report on First Nations' governance over education: Reclaiming the circle of learning and $2.05 \%$ in First Nations control of First Nations education: It's our vision, it's our time. 


\section{Theme 3: Sustainability}

Sustainability is defined as survival/preservation of First Nations language, cultures, traditions and communities. Cultural survival/preservation is related to the integration of First Nations culture into the classroom and to learner's cultural bonding and cultural knowledge. The following are the categories/rationales that were coded under the theme sustainability: community acceptance, language and culture, identity and preserving history/tradition. These rationales/categories taking together contribute to First Nations capacity to preserve their culture and survive as a cultural community. Below is a report on the frequency of the categories/rationales.

\section{Community Acceptance}

The rationale, community acceptance, is defined as the participation of First Nations members of the community including parents, elders and leaders in the learning process.

Sentences or phrases that expressly stated or suggested community acceptance as a rationale for

First Nations run schools were coded. The following sentences are examples:

It said First Nations education will remain a holistic approach that incorporates a deep respect for the natural world. First Nations language and cultural values are taught and enhanced through education and the education process actively involves many partners - parents, the community, and the school (Chiefs of Ontario, 2004, p. 10).

Educators within the education systems encourage community members to get involved in making educational decision, involve community members in the learning process and focus on knowledge and skills that enable First Nations children to function appropriately in their community and mainstream society (Chiefs of Ontario, 2004, p.2).

Community acceptance was found in 4 of the 6 documents. It was referenced a total of 24 times. It was referenced $2.59 \%$ in Elements of quality First Nations education systems; $1.49 \%$ in Standards for quality education: Towards a framework for affective and effective schools in a 
First Nations environment; $3.54 \%$ in the document Report on First Nations' governance over education: Reclaiming the circle of learning and $2.59 \%$ in First Nations control of First Nations education: It's our vision, it's our time.

\section{Language and Culture}

The rationale, language and culture, is defined as the inclusion of the home language and/or culture in the education system for the survival and preservation of First Nations. The following sentence explicitly expressed 'language and culture' as a rationale: "Education is the transmission of cultural DNA from one generation to the next. It shapes the language and pathways of thinking, the contours of character and values and the social skills and creative potential of the individual" (Powless, 2004, p. 1).

Language and Culture was found in all 6 documents. It was referenced a total of 34 times. It was referenced $2.00 \%$ in the document First Nations Action Plan; $1.38 \%$ in Elements of quality First Nations education systems; $0.60 \%$ in Standards for quality education: Towards a framework for affective and effective schools in a First Nations environment; $0.90 \%$ in The new agenda: Building upon the history of First Nations education in Ontario; $0.39 \%$ in the document Report on First Nations' governance over education: Reclaiming the circle of learning and $3.68 \%$ in First Nations control of First Nations education: It's our vision, it's our time. Identity

The rationale, identity, can be defined as a child's ability to identify with pride their membership in a cultural community. One of the means to foster identify is through education (Craven, 1999). The following sentences were coded as identity:

We want education to give our children a strong sense of identity with confidence in their personal worth and ability we believe in education as a preparation for total living, as a means of free choice of where to live and work, and as a means 
of enabling us to participate fully in our social, political and educational advancement (Chiefs of Ontario, 2004, p. 9).

The education of Native peoples should reinforce their culture and their identity (as they define them) rather than destroying them (Chiefs of Ontario, 2004, p. 3).

She stated that First Nations have stated two goals in education - to safeguard and protect their cultural identities and prepare their children for a modern world with the knowledge and skills necessary to survive and prosper (Chiefs of Ontario, 2004, p.10).

Identity was found in 3 of the 6 documents. It was referenced a total of 13 times. It was referenced $1.12 \%$ in the document First Nations Action Plan; $2.15 \%$ in Elements of quality First Nations education systems and $1.06 \%$ in First Nations control of First Nations education: It's our vision, it's our time.

Preserving History/ Traditions

The rationale, preserving history/traditions, is defined as curricula that addresses, recognizes and/or incorporates the history of First Nations in Canada. The following sentence explicitly stated preserving history/traditions as a rationale for a First Nations run school: "Selfdetermined, culturally appropriate educational processes in which Aboriginal history, culture, languages, philosophies of life and social organization shall be given an utmost priority as important parts of the curriculum" (Wesley-Esquimaux, 2004, p. 3).

Preserving history/traditions was found in all 6 documents. It was referenced a total of 21 times. It was referenced $0.63 \%$ in the document First Nations Action Plan; $4.55 \%$ in Elements of quality First Nations education systems; $2.03 \%$ in Standards for quality education: Towards a framework for affective and effective schools in a First Nations environment; $0.47 \%$ in The new agenda: Building upon the history of First Nations education in Ontario; $0.39 \%$ in the document 
Report on First Nations' governance over education: Reclaiming the circle of learning and $1.29 \%$ in First Nations control of First Nations education: It's our vision, it's our time.

A summary of the frequency of each rationale discussed in previous sections is provided in the chart below. It illustrates a pictorial view of the amount of times each rationale, within the three themes, were mentioned. The chart identifies the most common and least common rationales for First Nations run schools in Ontario. An analysis of the frequency of the rationales will be explored in the next chapter.

Chart 1: Frequency of Rationales Summary

\begin{tabular}{|l|c|}
\hline \multicolumn{1}{|c|}{ Rationale } & Frequency of Reference \\
\hline Self-Governance over Education & 59 \\
\hline Self-Government & 37 \\
\hline Improvement of Socio-Economic Conditions & \\
\hline Outcomes & 24 \\
\hline Sustainability & 34 \\
\hline Community Acceptance & 13 \\
\hline Language and Culture & 21 \\
\hline Identity & \\
\hline Persevering History/Traditions & \\
\hline
\end{tabular}

In contrast to manifest content analysis, which calculated the frequency of the rationales, a latent content analysis was conducted to understand the underlying meaning for the rationales provided by First Nations leaders and scholars. In the next section, the results from the latent content analysis are described. 
The manifest content analysis revealed three themes: self-governance over education, improvement of socio-economic conditions and sustainability. Underlying all of these rationales is an implicit assumption that First Nations need greater control over their education system. For example, self-governance over education is not possible without greater control. A closer look at each theme will demonstrate how the documents support the notion that First Nations need greater control and why such control is necessary.

First Nations leaders and scholar have maintained, within the documents, that selfgovernance over education cannot occur without greater control. The following are examples of how their perspectives were articulated:

Enhanced education outcomes for all First Nation learners requires the recognition of First Nations jurisdiction over education at all levels, and the provision of adequate long-term and sustainable funding arrangements (Assembly of First Nations, 2005, p.1).

In the past, the Canadian governments' education policy has been a tool of oppression, but it can be a tool of liberation founded on First Nation control over education (Assembly of First Nations, 2010, p 4).

Thus, recognition of First Nations jurisdiction and authority to govern their education systems, and the resources to build their capacity, go hand in hand (Chiefs of Ontario, 2004, p. 1).

In a First Nation setting jurisdiction is an essential element to determining the quality, affect, effect, and general standards of, education that can be provided at the community level (McDonald, 2004, p. 5).

First Nations leaders and scholars argued in many documents that the first step to selfgovernance over education is that the federal government needs to recognize Fins Nations authority. Full authority is needed for First Nations to fully recover from their colonial experience (Viruru, 2005). Moreover, First Nations full authority over their efucation may ensure that their social and economic conditions may improve. 
First Nations are familiar with the needs of their students and the necessary knowledge skills needed to become active members in society. The following examples illustrate this familiarity:

All First Nations learners require a wide variety of opportunities that will nurture their learning and allow them to acquire the necessary skills and knowledge to actively and positively participate in, and contribute to, their families, clans, Nations, society and the global community (Assembly of First Nations, 2010, p. 8).

Although factors other than education can affect the demand for social assistance, it has been demonstrated that education, or lack of it, is directly related to jobs, income levels and the potential for well being (McDonald, 2004, p.9).

First Nations have their children's best interests in mind and can develop curricula to meet their academic, personal and cultural needs. Greater control means that standard curricula can be developed across all First Nations schools that incorporate cultural components as well as bilingual elements for all students.

In the documents First Nations leaders and scholars claimed that sustainability cannot occur unless First Nations have greater control over their education system. With greater control, the language and culture of First Nations can become an integral part of children's learning experiences. The following texts support this goal:

First Nations education must be grounded in First Nations languages and cultural values, and must be properly funded so that education outcomes meet or exceed those of the general Canadian population (Assembly of First Nations, 2005, p.1).

Education is the vehicle for transmitting our language, social, cultural and traditional values to our children. It is our right, as First Nations, to decide what our children will learn, as we have for many generations in the past, before the arrival of the Europeans on our shore. It is critical in the exercise of First Nations government that we, as First Nations, assert our jurisdiction over our education systems (Chiefs of Ontario, 2004, p. 8).

First Nations control over education will provide the means to acquire the necessary skills to be self-empowered and self-sufficient and to maintain First 
Nations cultural values and languages (Assembly of First Nations, 2010, p. 6)

Providing First Nations with jurisdiction over their education can aid in the implementation of solutions for the low high school graduation rates of First Nations students and decrease the graduation gap between First Nations learners and the non-Aboriginal population.

Currently, First Nations manage their education system, but they are not responsible for their own schools. This is expressly stated in sections 114 through 122 of the Indian Act:

The Governor in Council may authorize the Minister, in accordance with this Act, to enter into agreements on behalf of Her Majesty for the education in accordance with this Act of Indian children, with

(a) the government of a province;

(b) the Commissioner of Yukon;

(c) the Commissioner of the Northwest Territories;

(c.1) the Commissioner of Nunavut;

(d) a public or separate school board; and

(e) a religious or charitable organization (Indian Act, 1985).

The Indian Act is a reminder of how the government has previously and currently interfered with the education of First Nations learners. The Act is an enforced statute which contains colonist ideas and contradicts the apology made by the Canadian government in 2008 for their role in the operation of residential schools. The Prime Minister stated that "the government now recognizes that the consequences of the Indian Residential Schools policy were profoundly negative and that this policy has had a lasting and damaging impact on Aboriginal culture, heritage and language" (Prime Minister of Canada, 2008, p.1), 


\section{CHAPTER 4: DISCUSSIONS AND CONCLUSION}

The previous chapter outlined how rationales for Ontario First Nations run schools are comprised of three key themes: self-government over education, improvement of socioeconomic conditions and sustainability. The next section offers a close analysis of the implications of these rationales.

Based on the manifest content analysis, sustainability was the most common theme. This implies that this theme contains the most recognizable rationales for First Nation run schools in Ontario as the theme was referenced approximately 118 times. This theme, however, does not contain the most cited rationale, but rather contains the most rationales. For example, under the theme sustainability four rationales- community acceptance, language and culture, identity and preserving history/tradition emerged.

While the most cited theme is sustainability, a closer analysis revealed that the category of self-government may be the most important to First Nations leaders and scholars. This category was cited in each report at least 4 times. Both the Assembly of First Nations and Chiefs of Ontario were in agreement of the importance of self-government since the documents from the Assembly of First Nations cited the rationale 32 times while the Chiefs of Ontario cited it 27 times. This shared rationale may be surprising since the Assembly of First Nations only produced two documents compared to Chiefs of Ontario which had four documents. It would have been assumed that the latter would have provided the most citation for self-government. In addition to fewer documents, Assembly of First Nations also had fewer total page numbers (61 pages) compared to Chiefs of Ontario ( 76 pages). This finding could possibly be explained by the authors and purpose of each document. The documents from the Assembly of First Nations were written by the organization. The first document, First Nations education action plan, is a 
vision of their education system under their full control and jurisdiction. The second document, First Nations control of First Nations education: It's our vision, it's our time, is a policy paper that provided specific recommendations that "will enable the development and implementation of education legislation, governance frameworks, policies, programs and services for all levels of education" (Assembly of First Nations, 2010, p. 3). Both of these documents were published within the last five years, unlike the Chiefs of Ontario documents.

Chief of Ontario documents were all published in 2004 and none of the documents have the same author. The first one, The new agenda: Building upon history of First Nations education in Ontario, provided an overview of previous and current legislations affecting First Nations education in Ontario. The second document, Elements of a quality First Nations education system, written by the Chiefs of Ontario is a paper that "selectively review[ed] key reports and the recommendations which have been made over the thirty year period which have affirmed foundational elements of quality First Nations education systems" (Chiefs of Ontario, 2004, p. 1). The intention of the third document, Report on First Nations' governance over education: Reclaiming the circle of learning, was related to the rationale, self-government, more than any other document on this Chiefs of Ontario website as it discussed First Nations control over their education system.

The second most cited rationale, under the theme, improvement of socio-economic conditions, was social and economic outcomes. This rationale was referenced a total of 37 times throughout all 6 documents. The documents from the Assembly of First Nations cited the rationale 17 times while the Chief of Ontario documents cited it 20 times. This suggests that both First Nations organizations recognized the importance of social and economic outcomes as a rationale for First Nations run schools in Ontario. However, a further examination of the 
frequency of this rationale in each document has shown that it has become a growing issue among First Nations leaders and scholars. The Chief of Ontario documents were published earlier, all four documents found on the Chiefs of Ontario's website have cited the rationale at least three times and three of the four referenced it between three to five times. The fourth document, Standards for quality education: Towards a framework for affective and effective schools in a First Nations environment referenced the rationale nine times because it was the focus of the paper.

The Assembly of First Nations documents were written at a later time than those of the Chiefs of Ontario and have more references to social and economic outcomes. For example, the 2005 document, First Nations education action plan, referenced social and economic outcomes six times. That number may appear to be lower than expected, but this document contained ten pages which mean that the rationale covered $6.18 \%$ of the entire document. The Assembly of First Nations 2010 document cited the rationale more than any other one. This increase in frequency over time may be a result of the social and political context. The Auditor General's 2004 report on the current conditions of First Nations education and her recommendations to the Department of Indian and Northern Affairs Canada (Office of the Auditor General, 2004) may have motivated First Nations scholars and leaders to focus more on social and economic outcomes. Moreover, despite the increasing of focus on the issue First Nations, high school graduation rates remain consistently lower than of the non-Aboriginal population (Assembly of First Nations, 2005). These current issues may account for the increase of recognition of social and economic outcomes as an important rationale.

Sustainability was the most cited theme, but only contained the third most cited category/rationale. Language and culture was referenced a total of 34 times. The Assembly of 
First Nations cited this rationale 24 times compared to 10 times by the Chiefs of Ontario. The Assembly of First Nations document, First Nations control of First Nations education: It's our vision, it's our time, cited language and culture as a rationale more than any other document (22 times; making up $64.7 \%$ of the total times). The length, the currency and the authorship of the document may account for why the rationale language and culture is so prevalent. However, a closer examination indicated that length does not fully explain its frequency; rather the document simply had more to said about language and culture (with coverage at $3.68 \%$ ). Currency of the document is a better explanation because the preservation of language and culture continues to be a pressing concern for First Nations. The authorship of the document, however, may be the best explanation. Since 2007, the Assembly of a First Nations have developed and implemented strategies such as the National First Nations Language Strategy to recognize, protect and revitalize First Nations languages in Canada (McDonald, 2007). Specifically, this strategy aims to "increase the number of First Nations people who speak their language... [but in order to do this there needs to be an]... increase the opportunities for learning language. [This strategy also suggest that there is a need]...to increase the opportunities to use First Nations languages by increasing the number of circumstances and situations where First Nations languages can be used" (McDonald, 2007, p.11). Education provides the key opportunity for First Nations language to be learned.

It is important to explain the frequency of each rationale, but it is more important to understand what the rationales are really saying. The most common rationale was self government which fall under the theme, self-governance over education. First Nations have long argued that should have jurisdiction over the education of their learners. Giving First Nations' control means that parents, elders and First Nations education authorities will have legal 
authority to make changes to their education system by negotiating agreements and arrangements in order to improve students' educational opportunities (Minister's National Working Group on Education, 2002). Without jurisdiction over education, First Nations "cannot legally determine basic requirements for their learners' education such as curricula, language of instruction, education standards (academic, space etc.) teacher qualifications, the school calendar and pedagogical methods, or the creation of more First Nations schools and education facilities" (Minister's Working Group on Education, 2002, p.10). First Nations jurisdiction will allow for accountability in the areas of academic results, teacher performance and school evaluation.

The latent content analysis indicated that underlying all the rationales is the fundamental principle that First Nations should have full control over their education system. The key argument is that in order for First Nations to have control over education, the Canadian government needs to recognize their inherent right to self-government. First Nations have sought to gain "full inter-dependence with other governments in Canada within a constitutional framework which appropriately allocates governance jurisdictions according to the rights and capacities of each government to discharge them best" (Assembly of First Nations, 2008, p. 10). The reasoning behind this right stems from First Naitons history in Canada. Prior to contact, First Nations "had their own governments and ways of life" (Assembly of First Nations, 2008, p.10). After they entered into treaties with the Europeans and later with the Canadian government, First Nations were denied recognition of self-government (Assembly of First Nations, 2008). Recognition of self-government now will transform their current education conditions for First Nations learners. This need for recognition is articulated in the Royal Commission on Aboriginal Peoples; it reported that: 
Education is a core element of jurisdiction in Aboriginal self-government. Aboriginal people must have the opportunity to exercise self-governance in education. In so doing, they would resume control of their education in its entirety, passing their own legislation and regulating all aspects of education. Aboriginal nations, public governments and community of interest governments could all establish their own educational institutions under their own jurisdiction (Indian and Northern Affairs Canada, 1996, p. 8).

First Nations control over education will result in greater authority in the distribution of funding. As of 1996, there has been a $2 \%$ funding increase cap for First Nations programs and services (Assembly of First Nations, 2006). First Nations leaders and scholars have maintained that the current education situation will remain the same unless the $2 \%$ cap is abolished. The National Chief has stated that "the $2 \%$ cap hasn't kept pace with inflation or First Nations population growth. The cap has affected all programs and services for First Nations [students]...on-reserve[s]... Education is facing an acute crisis. If the existing funding mechanisms continue, there will be a funding shortfall of over a billion dollars in education by 2011" (Assembly of First Nations, 2006, p.1). In other words, even though there are schools managed by First Nations in which language and culture is supported, there is still, as the National Chief has stated an acute crisis in the First Nations education system.

The Assembly of First Nations reported in 2007 that the annual high school graduations rates of First Nations students ranged from 28.9 percent to 32.1 percent. They also estimated that it may take approximately 28 years before First Nations learners can graduate from high school at the same rate as non-Aboriginal students. In addition, there are serious social, economic, health, geographic and demographic issues within some First Nations communities. The Auditor General supported the idea that "education is critical to the social and economic strength of First Nations individuals and communities to a level enjoyed by other Canadians" (The Office of the Auditor General, 2004, p.2). Sufficient funding from the federal government for First Nations to 
govern their education is critical. Thus, the educational crisis must be addressed through recognition of self-government.

Recognition of self-government means that the Department of Indian and Northern Affairs Canada may have little involvement in the day to day operation of First Nations run schools. The Department's involvement is already under question by the Auditor General who has noted in her 2004 report that they have failed to clearly outline and defined their roles and responsibilities. This state of affairs provides an opening for First Nations to engage in selfgovernance and to design and implement their own roles and responsibility concerning a uniform education system. Standard curricula within all First Nations schools can be developed which incorporates the needs of First Nations learners. First Nations "have consistently stated that [in order] to have quality education system it first must be their own and it must have adequate resources. Thus, recognition of First Nations jurisdiction and authority to govern their education systems, and the resources to build their capacity, go hand in hand" (Chiefs of Ontario, 2008, p.1).

While this study has provided an overview of the rationales articulated by First Nations leaders and scholars since 2004 , it does have its limitations. Using content analysis as a data collection tool has a drawback. The examination is limited to recorded communications (Babbie and Benaquisto, 2002). While many oral, written or graphic communications are recorded, this research would have greatly benefited from interviews with First Nations scholars and leaders who would have enriched my understanding of their education system. Document analysis and interviews could be triangulated with actual observations of First Nations run schools to enhance an understanding of the rationales. This study focused on only two First Nations websites and 
thus there were limited data sources. A broader range of documents would have contributed to a deeper understanding of the rationales for First Nations run schools.

This study's findings have led to some recommendations for policy/law makers and for future researchers. These recommendations, as suggested by post-colonial theorists, focus on "the political, linguistic and cultural experiences of societies that were former European colonies" (Ashcroft, Griffith \& Tiffin, 2001, pp.186). The recommendations are also transformational and can result in significant social change. In order for First Nations to achieve quality education, funding needs to be comparable to provincial school standards. The time frame for which First Nations learners can graduate at levels comparable to the non Aboriginal levels can be reduced if funding is sufficient to ensure quality education. Funding should address building conditions; increase the number of qualified teachers and the integration of First Nations culture and language into curricula. The government must recognize that quality education and funding goes hand in hand. In addition to more funding, First Nations need greater control over their education system to achieve quality education. Greater control needs to be achieved through legislations and negotiated agreements with the federal government. Furthermore, researchers are encouraged to address the limitations of this current study, as well as determine if changes in the control and delivery of First Nations schools has an impact on sustainability of language and culture and long term social and economic outcomes.

In conclusion, I was inspired to conduct this study after visiting two First Nations run schools. My investigation took me through a content analysis of six documents that revealed the most common rationales for First Nations run schools in Ontario. At the end of my study, I have drawn upon the perspectives and words of First Nations leaders and scholars to envision an education system in which First Nations children have a choice to attend schools of the highest 
quality under the control of their community. However, to make this vision a reality First Nations leaders and scholars have stated that there is much work to be done by the federal government. Recognition of self-government through legations and negotiated agreements must be immediate. In a transformed education for First Nations children, all learners will have the "opportunities that will nurture their learning and allow them to acquire the necessary skills and knowledge to actively and positively participate in, and contribute to, their families, clans, Nations, society and the global community" (Assembly of First Nations, 2010, p. 8). 


\section{REFERENCES}

Abu-Rabia, S. (2005). The linguistic resources of Israel. Language, Culture \& Curriculum, 18(1), 1-2.

Ashcroft, B., Griffith, G. \& Tiffin, H. (2001). Key concepts in post-colonial studies. New York: Routledge.

Assembly of First Nations (1988). Traditions and Education: Towards a Vision of Our Future. Retrieved from http://www.afn.ca/calltoaction/Documents/DOFNJOE.pdf Assembly of First Nations (2005). First Nations education action plan. Retrieved from http://www.afn.ca/cmslib/general/Education-Action\%20Plan.pdf

Assembly of First Nations. (2006). Assembly of First Nations call on government of Canada to address First Nations education crisis. Retrieved from

http://64.26.129.156/article.asp?id=2499

Assembly of First Nations (2007). The reality for First Nations in Canada. Retrieved from http://www.afn.ca/article.asp?id=764

Assembly of First Nations. (2008). Federal funding to First Nations: The facts, the myths, and the way forward. Retrieved from

http://www.csfs.org/Files/Public/Index/Archive/Federal-Government-Funding-to-FirstNations.pdf

Assembly of First Nations. (2010). First Nations control of First Nations education: It's our vision, it's our time. Retrieved from http://www.afn.ca/calltoaction/Documents/FNCFNE.pdf Assembly of First Nations (2010). Indian control of Indian education. Retrieved from 
http://www.afn.ca/article.asp?id=830

Assembly of First Nations (2010). Description of the AFN. Retrieved from http://www.afn.ca/article.asp?id=58

Babbie, E., \& Benaquisto, L. (2002). Fundamentals of social research. Scarborough: Thomson Canada Limited.

Babbie, E. (2004). The practice of social research. Belmont: Thomson/Wadsworth.

Battiste, M. (2002). Indigenous knowledge and pedagogy in First Nations education: A literature review with recommendations. Retrieved from http:/www.usask.ca/education/people/battistem/ikp_e.pdf

Battiste, M. \& Barman, J. eds. (1995). First Nations education in Canada: The circle unfolds. Vancouver: UBC Press.

Binda, K. L. \& Calliou, S. (Eds.) (2001). Aboriginal education in Canada. Mississauga: Canadian Educators Press.

Cairney, T. H. (2002). Bridging home and school literacy: In search of transformative approaches to curriculum. Early Child Development and Care, 172, 153-172.

Canadian Constitution, 1982. Schedule B to the Canada Act, 1982 (U.K.), c. 11, (1982).

Canadian Council on Learning. (2009). The state of Aboriginal learning in Canada: A holistic approach to measuring success. Retrieved from http://www.cclcca.ca/pdfs/StateAboriginalLearning/SAL-FINALReport_EN.PDF

CBC News. (2008). PM cites 'sad chapter' in apology for residential schools. Retrieved from . http://www.cbc.ca/canada/story/2008/06/11/aboriginal-apology.html

Chiefs of Ontario. (2004). Elements of quality First Nations education systems. Retrieved 
from http://chiefs-of-

ontario.org/Assets/Elements\%20of\%20Quality\%20First\%20Nations\%20Education\%20S ystems.pdf

Chiefs of Ontario. (2004). Introduction. Retrieved from http://chiefs-ofontario.org/Assets/Introduction.pdf

Chiefs of Ontario. (2008a). About us: History. Retrieved from http://chiefs-ofontario.org/PageContent/Default.aspx?SectionID $=6 \&$ SectionHeadlineID $=27$

Chiefs of Ontario. (2008b). Welcome. Retrieved from http://chiefs-of-ontario.org/Default.aspx Craven, R. G. (1999). Inspiring students' hearts, minds, and deeds: The passion and power of Australian Aboriginal studies books. Bookbird, 37, 31-36.

Dacks, G. (2004). Implementing First Nations self-government in Yukon: Lessons for Canada. Canadian Journal of Political Science, 37, 671-694

Davin, N.F. (1879). Report on industrial schools for Indians and half-breeds. Ottawa: Confidential Report to the Minister of the Interior, 14 March 1879.

Dei, G. J. S (2008). Schooling as a community: Race, schooling, and the education of African youth. Journal of Black Studies, 38 (3), 346-366.

Faries, E. (2004). Research paper on Aboriginal curriculum in Ontario. Retrieved from http://chiefs-ofontario.org/Assets/A\%20Research\%20Paper\%20on\%20Aboriginal\%20Curriculum\%20in $\% 200$ ntario.pdf

First Nations Education Steering Committee. (2008). First Nations jurisdiction over education. Retrieved from http://www.fnesc.ca/jurisdiction/index.php Furniss, E. (1992). Victims of benevolence: The dark legacy of the williams lake 
residential school. Vancouver: Arsenal Pulp Press.

Gallagher-Hayashi, D. (2004). Connecting with Aboriginal students. Teacher Librarian [Seattle], 31, 20-24.

Gould, J. (2008). Non-standard assessment practices in the evaluation of communication in Australian Aboriginal children. Clinical Linguistics \& Phonetics, 22, 643-657.

Haig-Brown, C. (1991). Resistance and renewal: Surviving the Indian residential school. Vancouver: Arsenal Pulp Press

Hill, K. (2004). First Nations languages and education in Ontario. Retrieved from http://chiefs- ofontario.org/Assets/First $\% 20$ Nations \%20Languages\%20and $\% 20$ Education $\% 20 \mathrm{in} \% 200$ nt ario.pdf

Hill, R. J. (2004). Educating First Nations citizens: A rethinking of First Nations responsibility to educate their citizens. Retrieved from http://chiefs-of-ontario.org/Assets/Educating\%20First $\% 20$ Nations $\% 20$ Citizens.pdf. Indian Act, R.S., c. 1-5 (1876). Indian Act, R.S., c. I-5 (1985). Indian and Northern Affairs Canada (1996). Report of the Royal Commission on Aboriginal Peoples. Retrieved from http:/www.collectionscanada.gc.ca/webarchives/20071115053257/http:/www.aincinac.gc.ca/ch/rcap/sg/sgmm_e.html Indian and Northern Affairs Canada. 2006). First Nations. Retrieved from http://www.aincinac.gc.ca/ap/fn/index-eng.asp\#tphp 
Indian and Northern Affairs Canada. (2008) Background-education. Retrieved from http://www.ainc-inac.gc.ca/edu/ep/res-eng.asp

Indian and Northern Affairs Canada. (2008) Elementary/secondary education. Retrieved from http://www.ainc-inac.gc.ca/edu/ep/ese-eng.asp

Indian and Northern Affairs Canada. (2010). Aboriginal peoples and communities. Retrieved from http://www.ainc-inac.gc.ca/ap/index-eng.asp

Indian and Northern Affairs Canada. (2010). Terminology. Retrieved from http://www.ainc-inac.gc.ca/ap/tln-eng.asp

Jackson, M. (1992). In search of the pathways to justice: Alternative dispute resolution in Aboriginal communities. U.B.C. Law Review, 147-235.

Jaine, L. (ed.). (1993). Residential schools: The stolen years. Saskatoon: University Extension Press.

K Net Media. (2009). AFN national Chief responds to Prime Minister's statements on colonialism. Retrieved from http://media.knet.ca/node/7336

Kennedy, T. B (2006). First Nations want justice on 'land theft'. Retrieved from http://www.turtleisland.org/discussion/viewtopic,php?p=7223.

Krippendorff, K. (2004). Content analysis: An introduction to its methodology. Thousand Oaks, CA. Sage Publications.

Liberal Party of Canada. (2010). Biography. Retrieved from http://cynthiawesleyesquimaux.liberal.ca/biography/

McDonald, RA.J. (2004). Standards for quality education: towards a framework for affective 
and effective schools in a First Nations Environment. Prepared for the Chiefs of Ontario.

Retrieved from http://chiefs-of-

ontario.org/Assets/Standards $\% 200 \mathrm{f} \% 20 \mathrm{Quality} \% 20$ Education.pdf

McDonald, RA.J. (2007). Assembly of First Nations: National First Nations implementation plan. Retrieved from http://64.26.129.156/misc/nfnlsip.pdf

Mendelson, M. (2008). Improving education on reserves: A First Nations education authority act. Retrieved from http:/www.caledoninst.org/Publications/PDF/684ENG.pdf

Milloy, J. S. (1999). A national crime: The Canadian government and the residential school system, 1876 to 1986. Winnipeg: University of Manitoba Press.

Minister's Working Group on Education. (2002). Our children-keepers of the sacred knowledge.

Retrieved from http://dsp-psd.pwgsc.gc.ca/Collection/R41-9-2002E.pdf

Ministry of Education. (2001). The Ontario curriculum grades 1-8: Native languages. Retrieved

from http://www.edu.gov.on.ca/eng/curriculum/elementary/nativelang18curr.pdf

Ministry of Education. (2009). Elementary education. Retrieved from

http://www.edu.gov.on.ca/eng/elementary.html

Ministry of Education. (2009). Aboriginal education in Ontario. Retrieved from

http://www.edu.gov.on.ca/eng/aboriginal/supporting.html

Office of the Auditor General. (2000). Chapter 4: Indian and Northern Affairs Canada:

Elementary and secondary education. Retrieved from http://www.oag-

bvg.gc.ca/internet/docs/0004ce.pdf

Office of the Auditor General. (2004). Report of the Auditor General of Canada to the House of 
Commons: Chapter 5 Indian and Northern Affairs Canada-education program and postsecondary student support. Retrieved from http://www.oag-

bvg.gc.ca/internet/docs/20041105ce.pdf

Office of the Parliamentary Budget Officer. (2009). The funding requirement for First Nations s schools in Canada. Retrieved from http://www2.parl.gc.ca/sites/pbo-

$\mathrm{dpb} /$ documents/INAC_Final_EN.pdf

Powless, R. (2004). The new agenda: Building upon the history of First Nations education in Ontario. Retrieved from http://chiefs-of-ontario.org/Assets/The\%20New\%20Agenda.pdf Prime Minister of Canada. (2008). Prime Minister Harper offers full apology on behalf of Canadians for the Indian residential schools system. Retrieved from http://www.pm.gc.ca/eng/media.asp?id=2149

: QSR International. (2007). Overview. Retrieved from http://www.qsrinternational.com/products_nvivo.aspx Service Canada. (2008). Common experience payment (CEP). Retrieved from http://www.servicecanada.gc.ca/eng/goc/cep/index.shtml

Statistics Canada. (2008). 2006 census: A decade of comparable data on Aboriginal Peoples. Retrieved from http://www12.statcan.gc.ca/census-recensement/2006/ref/info/aboriginalautochtones-eng.cfm

Stout, M. D. \& Kipling, S. (2003). Aboriginal People, resilience and the residential school legacy. Retrieved from www.ahf.ca/downloads/resilience.pdf

The Aboriginal Healing Foundation. (2005). Reclaiming connections: Understanding residential school trauma among aboriginal people. Ottawa: Author.

The Legacy of Hope (2001) Where are the children? Healing the legacy of the residential 
schools. Retrieved from http://www.wherearethechildren.ca/en/lhf.html

Tillotson, T. (2002). Reparation for Native Americans: Another trail of tears. Retrieved from http:/goinside.com/02/1/repairs.html.

Treaties and Historical Research Centre. (1978). The historical development of the Indian Act. Ottawa: P.R.E. Group, Indian and Northern Affairs.

Trochim, W. M. K., (2006). Types of reliability. Retrieved from http://www.socialresearchmethods.net/kb/reltypes.php

Venne, S. H. (1981). Indian Acts and amendments 1868-1975: An indexed collection. Saskatoon: University of Saskatoon.

Waabiginoojii \& Anderson, D. (2004). Report on second level services for First Nations education current and future needs. Retrieved from http://chiefs-ofontario.org/Assets/Second\%20Level\%20Services $\% 20$ for $\% 20$ First $\% 20$ Nations $\% 20$ Educa tion $\% 20$ Current $\% 20$ and $\% 20$ Future $\% 20$ Needs.pdf

Walker, J. (2009).The Indian residential schools truth and reconciliation commission. Retrieved from http://www2.parl.gc.ca/Content/LOP/ResearchPublications/prb0848-e.pdf Warry, W. (2007). Ending denial: Understanding Aboriginal issues. Peterborough: Broadview Press.

Wesley-Esquimaux, C. (2004). Report on First Nations' governance over education: Reclaiming the circle of learning. Prepared for the Chiefs of Ontario Retrieved from http://chiefs-ofontario.org/Assets/Report\%20on\%20First\%20Nations\%20Governance\%20Over\%20Edu cation.pdf

Whyte, K. (2005). Options for dealing with abuse: Facilitator's guide. Retrieved from http://www.survivingthepast.ca/options.html 
Williamson, P. (1999). First Nations peoples. Toronto: Emond Montgomery Publication Limited.

Zimmerman, S. (1992). The revolving door of despair: Aboriginal involvement in the criminal justice system. U.B.C. Law Review, 367-425. 
APPENDIX A:

Summary of Analyzed Documents

Table I: Summary of Analyzed Documents

\begin{tabular}{|c|c|c|c|}
\hline $\begin{array}{c}\text { Title } \\
\text { of Documents }\end{array}$ & $\begin{array}{c}\text { Year of } \\
\text { Publication }\end{array}$ & $\begin{array}{c}\text { Number of } \\
\text { Pages }\end{array}$ & Structure of Documents \\
\hline $\begin{array}{l}\text { First Nations education } \\
\text { action plan. }\end{array}$ & 2005 & $\frac{4}{10}$ & $\begin{array}{l}\text { Vision of an education } \\
\text { action plan } \\
\text { - First Nations perspectives } \\
\text { on education } \\
\text { - The direction forward } \\
\text { - Policy direction for a First } \\
\text { - Nations education plan } \\
\text { - Elements of a First Nations } \\
\text { education action plan } \\
\text { - Conclusions }\end{array}$ \\
\hline $\begin{array}{l}\text { First Nations control of } \\
\text { First Nations education: } \\
\text { It's our vision, it's our } \\
\text { time. }\end{array}$ & 2010 & 51 & $\begin{array}{ll}\text { - } & \text { Discussions about the } 1972 \\
\text { policy paper } \\
\text { - } \\
\text { Overview and purpose of } \\
\text { paper. } \\
\text { - } \\
\text { - } & \text { Ereamble } \\
& 1972 \\
\text { - } & \text { First Nations learning } \\
\text { systems } \\
\text { - } \quad \text { Provincial and territorial } \\
\text { learning systems } \\
\text { - Recognitions of First } \\
\text { Nations languages and } \\
\text { identity } \\
\text { - First Nations control of First } \\
\text { Nations education policy } \\
\text { framework } \\
\text { - Outcomes of First Nations } \\
\text { control of First Nations } \\
\text { education } \\
\text { - Ext steps } \\
\text { - Conclusions }\end{array}$ \\
\hline $\begin{array}{l}\text { Standards for quality } \\
\text { education: towards a }\end{array}$ & & & $\begin{array}{ll}\text { - Introduction } \\
\text { - Scope of work }\end{array}$ \\
\hline
\end{tabular}




\begin{tabular}{|c|c|c|c|}
\hline $\begin{array}{l}\text { framework for affective } \\
\text { and effective schools in a } \\
\text { First Nations } \\
\text { environment }\end{array}$ & 2004 & 27 & $\begin{array}{l}\text { The methodology } \\
\text { - Discussions about essential } \\
\text { elements in education } \\
\text { - Key principles of quality } \\
\text { education } \\
\text { - Discussions about the } \\
\text { current education state } \\
\text { - Gaps and barriers in success } \\
\text { - Indicators of success for } \\
\text { effective schools } \\
\text { - Status quo: The cost were } \\
\text { discussed }\end{array}$ \\
\hline $\begin{array}{l}\text { The new agenda: } \\
\text { Building upon the history } \\
\text { of First Nations education } \\
\text { in Ontario }\end{array}$ & 2004 & 18 & $\begin{array}{ll}- & \text { First Nations in Ontario } \\
\text { - } & \text { First Nations jurisdiction } \\
\text { - } & \text { First Nations traditional } \\
\text { education practices } \\
\text { - } & \text { Covenant chain treaty } \\
& \text { relationships } \\
- & \text { The covenant chain } \\
- & \text { History of federal education } \\
& \text { policy } \\
- & \text { Attempts to recognize or } \\
\text { advance self government } \\
\text { - Summary }\end{array}$ \\
\hline $\begin{array}{l}\text { Report on First Nations' } \\
\text { governance over } \\
\text { education: Reclaiming } \\
\text { the circle of learning }\end{array}$ & 2004 & 18 & $\begin{array}{ll}\text { - } & \text { Introduction } \\
\text { - } & \text { Key concepts } \\
\text { - } & \text { Schools councils } \\
\text { - } & \text { School boards } \\
\text { - } & \text { Successful education system } \\
\text { - } & \text { Funding } \\
\text { - } & \text { Roles and obligations } \\
\end{array}$ \\
\hline $\begin{array}{l}\text { Elements of quality First } \\
\text { Nations education } \\
\text { systems }\end{array}$ & 2004 & 13 & $\begin{array}{ll}\text { - } & \text { Background } \\
\text { - } & \text { Recent approaches to } \\
& \text { education } \\
\text { - } & \text { First Nations jurisdiction } \\
\text { - } & \text { Conclusions } \\
\end{array}$ \\
\hline
\end{tabular}




\section{APPENDIX B:}

\section{Coding Work Sheet}

Name of Report

Report Citation

Author(s)

Key Words and/or phrases and emergent themes or topics:

Author's Notes

$0:-14.53$ 